\title{
GFI1B Gene
}

National Cancer Institute

\section{Source}

National Cancer Institute. GFI1B Gene. NCI Thesaurus. Code C24427.

This gene plays a role in transcriptional regulation and erythroid cell growth.

Translocations in the gene are associated with chronic myeloid leukemia. 